\title{
ANALISIS FAKTOR-FAKTOR YANG MEMPENGARUHI PENERIMAAN PETANI TERHADAP PRODUK REKAYASA GENETIKA
}

\author{
(Determinant Factors of Farmers Acceptance on Genetically Modified Organism (GMO) Product)
}

\author{
Guspri Devi Artanti ${ }^{1 *}$, Hardinsyah ${ }^{2}$, Dewa Ketut Sadra Swastika ${ }^{3}$, dan Retnaningsih ${ }^{4}$ \\ ${ }^{1 *}$ Alamat korespondensi: Universitas Negeri Jakarta (UNJ), Jl. Rawamangun Muka Jakarta Timur, \\ Tel: 021-4715094, Email: vie_artanti@yahoo.com \\ 2 Departemen Gizi Masyarakat, Fakultas Ekologi Manusia, Institut Pertanian Bogor, Bogor 16680. \\ 3 Pusat Analisis Sosial Ekonomi dan Kebijakan Pertanian, Jl. A Yani 70, Bogor, 16161. \\ 4 Departemen Ilmu Keluarga dan Konsumen, Fakultas Ekologi Manusia, Institut Pertanian Bogor, \\ Bogor 16680.
}

\begin{abstract}
This cross sectional study was aimed at analyzing determinant factors of farmer's acceptance on GMO Product. For these purpose 150 farmers was selected from Jombang District (East Java) and 150 rests was selected from Deli Serdang District (North Sumatera). A logistic regression was applied to analyze the determinant factors of farmer's acceptance on GMO. The result showed that determinant factor of farmer's acceptance was farmer's knowledge on GMO. The higher level of knowledge, the lower the acceptance. The knowledge of farmer's on GMO was different between the two areas. Another result of this study showed farmers expectation about GMO Food could be circulated it can give positive impact: high quality for their agriculture produce; increase the productivity of Indonesian agriculture; and more information and socialization about GMO Product from the government. The government preferably compiled the program to increase knowledge of the farmer's against GMO by carrying out the approach and giving of information and the fact about GMO in the field through the increased in the activity of farmer's involvement in the farmers group.
\end{abstract}

Key words: acceptance, farmer, Genetically Modified Organisms Product.

\section{PENDAHULUAN}

Bioteknologi adalah salah satu bentuk pemuliaan non konvensional yang dapat dipakai untuk meningkatkan mutu pemuliaan tanaman. Rekayasa genetika yang dikenal juga dengan istilah transgenik, merupakan salah satu teknik bioteknologi yang dilakukan dengan cara pemindahan gen dari satu makhluk hidup ke makhluk hidup lainnya. Perkembangan pemanfaatan teknologi modern rekayasa genetika (Genetically Modified Organism, GMO) melalui rekombinasi DNA, telah menghasilkan produk Rekayasa Genetika (PRG) atau tanaman transgenik yang mempunyai sifat-sifat baru yang diinginkan untuk mengatasi kendala utama dalam rangka meningkatkan produksi pertanian, dan menghasilkan produk pangan yang lebih berkualitas dan produk pakan dari tanaman transgenik, serta peningkatan daya saing produk di pasar global.

Sejak dilepas pada tahun 1996 untuk tujuan komersialisasi, aplikasi bioteknologi Produk Rekayasa Genetika (PRG) di dunia meningkat dengan pesat, terutama untuk produk pangan. Pada tahun 1997 luas tanam PRG di du- nia kurang dari 8 juta hektar. Pada tahun 2006 telah menjadi 102 juta hektar, meningkat 13 kali lipat. Pada tahun 2007 luas areal penanaman menjadi 114.7 juta hektar yang ditanam di 23 negara yang terdiri atas 11 negara industri dan 12 negara berkembang, dan peningkatan luas tanam yang besar tersebut adalah di USA, Argentina, Brazil, Canada, India dan China (ISAAA, 2007).

Penelitian dan uji coba lapang PRG telah dilakukan di Indonesia. Untuk tanaman pangan telah diujicobakan tanaman jagung, kedelai, kacang tanah, coklat, tebu, ubi jalar, kentang dan padi. Sedangkan untuk tanaman nonpangan telah dicobakan penanaman kapas jenis $B t$ di Sulawesi Selatan menjelang akhir tahun 2000. Namun Oleh Menteri Negara Lingkungan Hidup saat itu tidak disetujui karena dianggap bertentangan dengan Kesepakatan Cartagena. Selain aspek riset dan uji coba lapang, di Indonesia juga beredar beberapa produk PRG impor seperti kedelai dan jagung dan komponen-komponen dari kedelai dan jagung PRG. Berbagai komponen kedelai seperti isolat protein, lecithin dan lainnya diproduksi secara massal dari kedelai PRG, selain itu, gula sirup 
jagung diproduksi dari jagung PRG. Komponen-komponen ini digunakan untuk bahan tambahan pangan atau ingredient makanan/minuman dalam industri pangan. Demikian pula jagung PRG diimpor untuk pakan ternak dan hasil ternaknya dimakan penduduk Indonesia.

Kontroversial pangan rekayasa genetik seringkali mengundang masalah pelik yang merugikan petani (Hardinsyah, 2000) karena tidak mampu meningkatkan produktifitas yang lebih menguntungkan dibanding teknologi non PRG. Sebagian masyarakat memperkirakan introduksi PRG tersebut menimbulkan ketergantungan pada bibit PRG impor, dan kemungkinan gangguan lingkungan. Dalam jangka panjang, seharusnya pemerintah memfasilitasi riset-riset untuk pengembangan PRG lokal yang aman dan membangun pemahaman dan persepsi yang baik dan benar bagi semua stakeholders PRG sedini mungkin.

Tujuan yang ingin dicapai dalam penelitian ini yaitu mengetahui pengadaan dan peredaran PRG pangan dan non pangan di Indonesia, menganalisis penerimaan petani tentang PRG dan faktor-faktor yang mempengaruhinya, menganalisis pengetahuan petani tentang PRG, menganalisis persepsi petani tentang peredaran, dampak positif dan dampak negatif PRG, menganalisis hubungan antara tingkat pendidikan, pengetahuan dan persepsi responden tentang PRG, dan mengetahui harapan petani tentang PRG.

\section{METODE}

\section{Desain , Waktu dan Tempat}

Desain penelitian ini adalah cross sectional study. Penelitian dilaksanakan pada bulan Mei sampai November 2007. Penelitian ini merupakan bagian dari kegiatan penelitian yang dilakukan atas kerjasama antara Departemen Pertanian dan Institut Pertanian Bogor, melalui kegiatan Kerjasama Kemitraan Penelitian Pertanian dengan Perguruan Tinggi. Tempat penelitian dilakukan di masing-masing satu kabupaten dari provinsi terpilih yaitu Kabupaten Jombang, Jawa Timur dan Kabupaten Deli Serdang, Sumatera Utara. Lokasi-lokasi tersebut dipilih karena merupakan kabupaten sentra produksi daerah pertanian tanaman pangan, serta terdekat dari ibu kota provinsi.

\section{Cara Penarikan Contoh}

Populasi dalam penelitian ini adalah seluruh petani di propinsi Jawa Timur dan Suma- tera Utara. Dari populasi tersebut diambil sampel secara sengaja (purposive sampling) menjadi sampel yang mewakili unsur petani. Kriteria sampel petani adalah orang yang bekerja di lahan pertanian, baik lahan pertanian miliknya sendiri maupun menggarap lahan pertanian orang lain. Jumlah responden petani sebanyak 300 orang/responden yang mewakili 2 kabupaten di dua provinsi (150 responden/ kabupaten).

Satu kabupaten dipilih dari setiap provinsi dengan mempertimbangkan: a) Merupakan sentra produksi pangan dan produk pertanian (bila mungkin telah dikembangkan PRG, b) Memiliki kepadatan populasi yang tinggi dengan jumlah penduduk yang bekerja sebagai petani cukup banyak sehingga memudahkan dalam mencari responden. Dengan mempertimbangkan kemungkinan petani tersebar pada semua desa di kabupaten, maka dipilih lima desa dari setiap kabupaten dengan menggunakan dua kriteria tersebut di atas. Selanjutnya dari setiap desa dipilih 30 petani dengan cara berkonsultasi dengan petugas lapang pertanian dan/atau kepala desa.

\section{Jenis dan Cara Pengumpulan Data}

Jenis data yang dikumpulkan adalah data sekunder dan data primer. Data sekunder meliputi dokumen/laporan tentang penggunaan benih, luas tanam dan produksi produk rekayasa genetika (PRG) baik berupa pangan maupun non pangan. Dokumen tentang regulasi, kesepakatan, pedoman dan standar tentang atau yang berkaitan dengan PRG baik nasional maupun internasional.

Secara umum data primer yang dikumpulkan meliputi karakteristik responden, yang mencakup: usia, pendidikan, besar keluarga, sumber dan besar pendapatan, keikutsertaan responden dalam keanggotaan kelompok tani dan luas lahan yang diusahakan. Data tentang pengetahuan responden tentang PRG meliputi: pengetahuan responden tentang istilah PRG, sumber informasi PRG, peredaran dan penanaman PRG, manfaat dan pengaruh buruk PRG. Data untuk persepsi responden tentang PRG meliputi: Perserpsi responden tentang peredaran PRG, penanaman PRG, keberadaan PRG dalam kehidupan sehari-hari (pangan dan non pangan). Data untuk penerimaan responden terhadap PRG meliputi: penerimaan responden terkait informasi tentang manfaat dan kerugian ekonomi dan lingkungannya serta tindakan responden terhadap Produk Rekayasa Genetika (PRG) bagi dirinya dan bagi orang di sekitarnya. Data harapan responden terhadap PRG 
terkait produksi, penyediaan, pengaturan (regulasi) dan informasi tentang PRG. Data primer tersebut dikumpulkan melalui wawancara terstruktur menggunakan kuesioner yang dipersiapkan dan diuji coba sebelumnya.

\section{Pengolahan dan Analisis Data}

Entry data primer dari responden penelitian dilakukan menggunakan program Excel. Data karakteristik yang berupa umur, pendidikan, sumber pendapatan, besar pengeluaran pangan dan non pangan, keanggotaan dan status keanggotaan dalam kelompok tani diberi kriteria untuk kategori dan di analisis secara deskriptif. Analisis perbedaan karakteristik responden di dua kabupaten mengenai pengetahuan, persepsi dan penerimaan terhadap PRG dilakukan dengan menggunakan uji $\mathrm{t}$ ( $t$ test). Untuk melihat hubungan antara tingkat pendidikan petani dengan pengetahuan dan persepsi tentang PRG digunakan korelasi Spearman's dan untuk menganalisis faktorfaktor yang memberikan pengaruh pada penerimaan petani terhadap PRG digunakan analisis regresi logistik. Analisis statistik dilakukan dengan menggunakan progran SPSS (Statistics Product \& Service Solution) Versi 15.0 for windows.

\section{HASIL DAN PEMBAHASAN}

\section{Pengadaan dan Peredaran PRG di Indonesia}

Data dari Departemen Pertanian menyatakan bahwa status tanaman PRG terutama tanaman pangan masih dalam tahap penelitian dan pengembangan di tingkat institusi dan belum ada tanaman PRG yang telah dilepas untuk ditanam secara luas di Indonesia. Satu-satunya produk PRG yang telah dilepas di masyarakat adalah kapas Bolgard di Sulawesi Selatan (Mulya et al, 2003). Pemerintah Indonesia telah mengambil sikap pro dengan penuh kehatihatian dalam pengembangan tanaman transgenik di Indonesia. Tanaman transgenik yang akan dilepas di Indonesia diuji melalui penelitian dan pengembangan yang baik, terencana, dan berkelanjutan. Pengambilan keputusan untuk mengembangkan tanaman transgenik di berbagai daerah perlu dilakukan melalui proses penelitian dan pengembangan yang terpadu antara pemerintah, perguruan tinggi, pelaku bisnis, LSM, swasta, dan masyarakat.

Selain aspek riset dan uji coba lapang, di Indonesia juga beredar beberapa produk PRG import seperti kedelai dan jagung dan komponen-komponen dari kedelai dan jagung.
Berbagai komponen kedelai seperti isolat protein, lecithin dan lainnya diproduksi secara massal dari kedelai PRG. Selain itu, gula sirup jagung dibuat dari jagung PRG. Komponenkomponen ini digunakan untuk bahan tambahan pangan atau ingredient makanan/minuman dalam industri pangan. Demikian pula jagung PRG diimpor untuk pakan ternak yang hasil ternaknya dimakan penduduk Indonesia. Santosa (2002) menyebutkan bahwa bahan pangan dari tanaman transgenik telah masuk ke Indonesia, terutama kedelai dan jagung, sedangkan pemerintah sendiri belum melakukan kajian untuk menetapkan jenis kedelai, jagung dan bahan pangan transgenik apa saja yang boleh masuk ke Indonesia. Hasil penelitian YLKI selama tahun 2002 sampai tahuan 2005 menyatakan bahwa telah ditemukan kandungan transgenik pada 10 produk pangan yang beredar di Indonesia. Produk-produk tersebut diantaranya adalah produk tahu, tempe dan susu kedelai (Anonim, 2006). Selain itu, berdasarkan laporan USDA yang berjudul Agricultural Biotechnology Report diketahui bahwa sejumlah produk pertanian (berupa jagung Bt, kedelai tahan herbisida serta bungkilnya) yang diimpor Indonesia dari Amerika merupakan pangan transgenik.

Swastika dan Hardinsyah (2008) menyatakan bahwa Indonesia mengimpor tidak kurang dari 300 ribu ton beras, dan masingmasing sekitar 1 juta ton jagung dan kedelai tiap tahun. Sebagian besar (71\%) jagung diimpor dari Argentina dan (83\%) kedelai dari Amerika serikat, dimana PRG untuk kedua komoditas ini berkembang dengan pesat. Tidak tertutup kemungkinan bahwa semua jagung dan kedelai yang diimpor adalah produk transgenik. Lebih lanjut Swastika dan Hardinsyah (2008) mengungkapkan bahwa Indonesia berada pada posisi yang sulit untuk menghindari masuknya PRG. Di satu sisi jumlah penduduk yang padat menghendaki penyediaan pangan yang selalu melampaui kemampuan produksinya, disisi lain sulit memperoleh pasokan jagung dan kedelai dari negara yang tidak mengembangkan teknologi transgenik dalam proses produksi kedua komoditas ini. Secara legal formal, Indonesia telah melakukan upaya perlindungan dengan mengeluarkan berbagai undang-undang dan peraturan pemerintah tentang pangan, keamanan hayati, dan keamanan pangan produk pertanian rekayasa genetik. Hal ini mencerminkan kepedulian pemerintah secara formal untuk melindungi masyarakat dari kemungkinan pengaruh negatif pangan PRG. Hasil kegiatan rekayasa genetika yang diharapkan sesuai dengan undang-undang 
adalah jenis, spesies, atau varietas baru yang mempunyai keunggulan dalam hal produktivitas dan kualitas hasil. Ini berarti bahwa PRG diharapkan dapat menyumbang produksi pangan bermutu melalui peningkatan produktivitas dan mutu hasil.

\section{Keadaan Umum Petani}

Mayoritas jenis kelamin petani pada penelitian ini adalah laki-laki (88.7\%) dan sisanya perempuan sebanyak $11.3 \%$ (Tabel 1). Secara umum mayoritas tingkat pendidikan petani ialah SD (64\%), SMP sebanyak 20.3\% dan tidak ada tingkat pendidikan petani yang mencapai perguruan tinggi. Sumber pendapatan utama petani adalah dari pertanian pangan sebanyak 99\% dan sebanyak $1 \%$ dari pertanian non pangan, dimana mayoritas petani bekerja sebagai buruh $(44.0 \%)$ sebagai sumber pendapatan lain untuk mencukupi kebutuhan hidup keluarganya. Sebanyak 53.0\% petani terdaftar dalam kelompok tani yang ada di kecamatan mereka.

\section{Penerimaan Petani terhadap PRG}

Hasil analisis penerimaan petani terhadap PRG dihitung berdasarkan skor total yang diperoleh dengan menjumlahkan beberapa pertanyaan terkait dengan penerimaan petani terhadap produk rekayasa genetika. Berdasarkan hasil penelitian diketahui $59.7 \%$ petani menyatakan menerima PRG dan $40.3 \%$ petani tidak menerima PRG. Dengan tingkat pengetahuan yang kurang memadai dan keterbatasan informasi yang ada mengenai PRG, petani akan sulit mengambil sikap untuk menerima atau tidak menerima PRG. Ini merupakan hal yang wajar dan logis jika responden bersikap hatihati, namun juga tidak bersikap ekstrim untuk menolak.

Skor penerimaan terhadap PRG pada petani di kabupaten Deli Serdang lebih baik (rata-rata $80.56 \pm 20.911$ ) bila dibandingkan dengan skor penerimaan petani di Kabupaten Jombang $(58.45 \pm 11.99)$. Hal ini berarti petani

Tabel 1. Sebaran Petani berdasarkan Karakteristik

\begin{tabular}{|c|c|c|c|c|c|c|c|}
\hline \multirow{2}{*}{ No } & \multirow{2}{*}{ Karakteristik Petani } & \multicolumn{2}{|c|}{ Jombang } & \multicolumn{2}{|c|}{ Deli Serdang } & \multicolumn{2}{|c|}{ Total } \\
\hline & & $\mathrm{n}$ & $\%$ & $\mathbf{N}$ & $\%$ & $\mathrm{n}$ & $\%$ \\
\hline \multirow[t]{3}{*}{1} & Jenis Kelamin & & & & & & \\
\hline & 1. Laki-Laki & 127 & 84.7 & 139 & 92.7 & 266 & 88.7 \\
\hline & 2. Perempuan & 23 & 15.3 & 11 & 7.3 & 34 & 34 \\
\hline \multirow[t]{4}{*}{2} & Umur (thn) & & & & & & \\
\hline & 1. $20-40$ & 31 & 20.7 & 36 & 24.0 & 67 & 22.3 \\
\hline & 2. $40-60$ & 83 & 55.3 & 86 & 57.3 & 169 & 56.3 \\
\hline & 3. $>60$ & 36 & 24.0 & 28 & 18.7 & 64 & 21.3 \\
\hline \multirow[t]{6}{*}{2} & Pendidikan Formal & & & & & & \\
\hline & 1. Tidak sekolah & 0 & 0 & 14 & 9.3 & 14 & 4.7 \\
\hline & 2. SD & 106 & 70.7 & 86 & 57.3 & 192 & 64.0 \\
\hline & 3. SLTP & 29 & 19.3 & 32 & 21.3 & 61 & 20.3 \\
\hline & 4. SLTA & 15 & 10.0 & 18 & 12.0 & 33 & 11.0 \\
\hline & 5. Perguruan Tinggi & 0 & 0 & 0 & 0 & 0 & 0 \\
\hline \multirow[t]{3}{*}{3} & Sumber pendapatan utama & & & & & & \\
\hline & 1. Pertanian Pangan & 150 & 100 & 147 & 98.0 & 297 & 99.0 \\
\hline & 2. Pertanian non - Pangan & 0 & 0 & 3 & 2.0 & 3 & 1.0 \\
\hline \multirow[t]{6}{*}{4} & Sumber pendapatan Lain & & & & & & \\
\hline & 1. Jasa & 38 & 25.3 & 6 & 4.0 & 44 & 14.7 \\
\hline & 2. Buruh & 71 & 47.3 & 61 & 40.7 & 132 & 44.0 \\
\hline & 3. Industri & 10 & 6.7 & 1 & 0.7 & 11 & 3.7 \\
\hline & 4. Lainnya & 0 & 0 & 50 & 33.3 & 50 & 16.7 \\
\hline & 5. Tidak ada & 31 & 20.7 & 32 & 21.3 & 63 & 21.0 \\
\hline \multirow{3}{*}{5} & Terdaftar dalam perkumpulan/ kelompok tani & & & & & & \\
\hline & 1. Ya & 105 & 70.0 & 54 & 36.0 & 159 & 53.0 \\
\hline & 2. Tidak & 45 & 30.0 & 96 & 64.0 & 141 & 47.0 \\
\hline \multirow[t]{4}{*}{6} & Lama menjadi anggota kelompok tani (tahun) & & & & & & \\
\hline & 1. $1-10$ & 66 & 62.9 & 38 & 25.3 & 104 & 65.4 \\
\hline & 2. $10-20$ & 31 & 29.5 & 14 & 9.3 & 45 & 28.3 \\
\hline & 3. $>20$ & 8 & 7.6 & 2 & 1.3 & 10 & 6.3 \\
\hline \multirow[t]{4}{*}{7} & Status keanggotaan dalam kelompok tani & & & & & & \\
\hline & 1. Ketua kelompok & 7 & 6.7 & 4 & 2.7 & 11 & 6.9 \\
\hline & 2. Anggota & 92 & 87.6 & 50 & 33.3 & 142 & 89.3 \\
\hline & 3. Lainnya & 6 & 5.7 & 0 & 0 & 6 & 3.8 \\
\hline
\end{tabular}


di kabupaten Deli Serdang lebih terbuka untuk menerima dan menggunakan PRG pangan maupun non pangan. Hasil analisis penerimaan tersebut, didukung oleh hasil uji t yang dilakukan untuk melihat perbedaan penerimaan antara petani di kabupaten Jombang dan petani di Kabupaten Deli Serdang. Dari hasil pengujian diperoleh nilai $t$ hitung sebesar -11.236 dengan signifikansi 0.000 , dimana nilai signifikansi tersebut lebih kecil dari a 0.01 , sehingga dapat disimpulkan bahwa terdapat perbedaan yang nyata dalam penerimaan PRG pada petani di dua wilayah tersebut (Tabel 3).

\section{Faktor yang Mempengaruhi Penerimaan PRG}

Uji regresi dilakukan untuk melihat faktor yang diduga mempengaruhi penerimaan petani terhadap PRG. Dalam Uji regresi logistik ini variabel penerimaan petani di bagi menjadi dua kategori, yaitu 1) bila skor penerimaan petani terhadap PRG > 60, dikategorikan menerima dan 0) bila skor penerimaan petani terhadap PRG < 60 dikategorikan tidak menerima. Hasil analisis menunjukkan bahwa hanya variabel pengetahuan yang nyata mempengaruhi penerimaan petani terhadap PRG, dengan nilai signifikansi sebesar 0.040 , dimana nilai tersebut $<0.05$ (Tabel 3). Namun, nilai Beta (B) dari komponen pengetahuan menunjukkan hasil -0.787 sehingga dapat disimpulkan bahwa makin tahu responden tentang keberadaan PRG, penerimaannya terhadap PRG semakin kurang. Pengetahuan tentang PRG diperoleh petani dari berbagai sumber seperti televisi, anggota kelompok tani/teman dan dari penyuluh pertanian. Diduga petani belum secara detail mendapatkan informasi tentang PRG terutama tentang manfaat dan kebaikan PRG. Petani baru sekedar tahu bahwa ada PRG, namun belum punya pemahaman yang lebih rinci tentang apa itu PRG dan apa yang dihasilkan, serta belum melihat secara nyata hasil pertanian atau produk pangan melalui rekayasa genetika secara langsung, sehingga petani bersikap waspada dan penuh kehati-hatian. Selain itu dimungkinkan karena usia rata-rata responden yang berada pada rentang 40-60 tahun (tabel 1), dimana pada usia ini cenderung sulit untuk menerima sesuatu yang baru dan perlu waktu untuk menerima teknologi/inovasi baru yang sama sekali belum pernah mereka lakukan. Dalam hal ini teknologi PRG dianggap sesuatu yang baru dan belum tampak secara nyata hasil dan dampaknya bagi sistem pertanian bila dibandingkan dengan sistem pertanian yang selama ini dilakukan, sebab PRG belum berkembang secara luas.

Tabel 2. Hasil Uji Regresi Logistik Faktor yang Mempengaruhi Penerimaan PRG pada Petani

\begin{tabular}{lcrr}
\hline \multicolumn{1}{c}{ Variabel } & B & \multicolumn{1}{c}{ Sig. } & Exp(B) \\
\hline Pengetahuan & -0.787 & $0.040^{*}$ & 0.455 \\
Persepsi & -0.329 & 0.266 & 0.719 \\
Pendidikan & 0.101 & 0.701 & 1.107 \\
Kelompok tani & 0.395 & 0.107 & 1.484 \\
Pendapatan & 0.014 & 0.959 & 1.014 \\
Constant & 0.887 & 0.021 & 2.428 \\
\hline
\end{tabular}

$*$ nyata pada taraf $5 \%$

\section{Pengetahuan tentang PRG}

Berdasarkan hasil analisis diketahui bahwa hanya $14.3 \%$ petani mempunyai tingkat pengetahuan yang baik tentang PRG, dimana skor pengetahuan petani tentang PRG di kabupaten Deli Serdang lebih baik (rata-rata $46.67 \pm$ 17.825) bila dibandingkan dengan skor pengetahuan petani di Kabupaten Jombang (ratarata $58.45 \pm 11.99$ ). Kurangnya tingkat pengetahuan petani terhadap PRG diduga karena rendahnya tingkat pendidikan petani dan kurangnya informasi dan sosialisasi tentang PRG dari instansi terkait. Rendahnya tingkat pengetahuan responden tentang transgenik dapat dipahami, karena ilmu pengetahuan tentang transgenik di Indonesia tergolong masih baru, terutama bagi petani. Pemahaman akan PRG mayoritas dimengerti kalangan ilmuwan dan mahasiswa yang biasa bersumber dari buku, publikasi ilmiah dan majalah. Hasil penelitian dari Bermawie et al (2003), menunjukkan bahwa hanya $35 \%$ responden (terdiri dari pengolah kedelai, pedagang, aparat pemerintah, mahasiswa, ilmuwan dan ibu rumah tangga) yang betul-betul paham tentang transgenik.

Tabel 3. Sebaran Tingkat Penerimaan Petani terhadap PRG

\begin{tabular}{lcccccccc}
\hline \multirow{2}{*}{ Kategori } & \multicolumn{2}{c}{ Jombang } & \multicolumn{2}{c}{ Deli Serdang } & \multicolumn{2}{c}{ Total } & \multicolumn{2}{c}{$\boldsymbol{t}$ Test } \\
\cline { 2 - 9 } & $\mathrm{n}$ & $\%$ & $\mathrm{n}$ & $\%$ & $\mathrm{~N}$ & $\%$ & $\mathrm{t}$ & sig \\
\hline Menerima & 56 & 37.3 & 122 & 82.0 & 179 & 59.7 & -11.236 & $0.000^{* *}$ \\
Tidak Menerima & 94 & 62.7 & 27 & 18.0 & 121 & 40.3 & & \\
Total & 150 & 100 & 150 & 100 & 300 & 100 & & \\
Rata-rata \pm SD & $58.45 \pm 11.99$ & $80.56 \pm 20.911$ & $69.50 \pm 20.30$ & & \\
\hline
\end{tabular}

** = nyata pada taraf $1 \%$ 
Dari hasil Uji t yang dilakukan untuk melihat perbedaan pengetahuan antara petani di kabupaten Jombang dan petani di Kabupaten Deli Serdang diperoleh nilai $T$ hitung sebesar -3.861 dengan signifikansi 0.00 , dimana nilai signikansi tersebut lebih kecil dari $\alpha=0.05$, sehingga dapat disimpulkan bahwa terdapat perbedaan yang nyata pada tingkat pengetahuan petani terhadap PRG di dua wilayah tersebut.

\section{Persepsi tentang PRG}

Berdasarkan hasil analisis diketahui bahwa $80.3 \%$ petani memiliki persepsi menerima terhadap PRG. Meskipun tingkat pemahaman petani secara umum masih sangat terbatas, namun petani bersedia memberikan persepsinya tentang PRG, baik dari peredaran, manfaat dan kerugian dari PRG. Mayoritas petani setuju jika di Indonesia telah beredar produk pangan dan non pangan PRG. Sekitar 68\% petani setuju jika pangan PRG mempunyai kualitas yang baik, $96.3 \%$ petani menyatakan setuju bahwa ketika pemerintah akan melepas PRG, hendaknya ada informasi dan keterbukaan kebijakan. Selain itu sebanyak $66 \%$ petani menyatakan bahwa PRG yang diperuntukkan bagi manusiai dan ternak harus melalui uji keamanan sebelum diedarkan dan $65.8 \%$ menyatakan bahwa pangan PRG harus mencantumkan label pada kemasannya.

Berdasarkan tabel 5, terlihat bahwa skor menerima untuk persepsi petani tentang PRG di kabupaten Jombang sedikit lebih baik (ratarata $74.29 \pm 15.387$ ) bila dibandingkan dengan skor persepsi petani di Kabupaten Deli Serdang (rata-rata $70.50 \pm 16.886$ ). Dari hasil Uji t yang dilakukan untuk melihat perbedaan persepsi antara petani di kabupaten Jombang dan petani di Kabupaten Deli Serdang diperoleh nilai t hitung sebesar 2.030 dengan signifikansi 0.360 , dimana nilai signikansi tersebut lebih besar dari a 0.05, sehingga dapat disimpulkan bahwa tidak terdapat perbedaan yang nyata untuk persepsi petani tentang PRG di dua wilayah tersebut, dimana presentasi petani yang menerima PRG hampir sama banyaknya pada kedua wilayah.

\section{Hubungan Pendidikan dengan Pengetahuan dan Persepsi Petani tentang PRG}

Hasil analisis statistik menggunakan korelasi Spearman, menunjukkan bahwa variabel pendidikan mempunyai hubungan yang erat terhadap variabel pengetahuan dengan angka signifikansi $<0.01$ yaitu 0.001 , dimana semakin tinggi tingkat pendidikan petani akan semakin tinggi pula tingkat pengetahuan atau pemahamannya tentang PRG atau semakin mudah dalam menerima informasi tentang PRG. Akan tetapi variabel pendidikan tidak mempunyai hubungan yang erat dengan variabel persepsi, angka signifikansinya $>0.01$, yaitu 0.879 . Persepsi petani tentang PRG tidak dipengaruhi tingkat pendidikannya yang rendah atau tinggi. Diduga persepsi petani terhadap PRG didasarkan pada asumsi bahwa dengan adanya teknologi baru dianggap akan meningkatkan produktivitas pertanian dan layak untuk diterima.

Tabel 4. Sebaran Tingkat Pengetahuan Petani terhadap PRG

\begin{tabular}{cccccccccc}
\hline \multirow{2}{*}{ Kategori } & \multicolumn{2}{c}{ Jombang } & \multicolumn{2}{c}{ Deli Serdang } & \multicolumn{2}{c}{ Total } & \multicolumn{2}{c}{ Test } \\
\cline { 2 - 9 } & & $\mathrm{n}$ & $\%$ & $\mathrm{n}$ & $\%$ & $\mathrm{~N}$ & $\%$ & $\mathrm{t}$ & sig \\
\hline Baik & $(>60 \%)$ & 10 & 6.6 & 33 & 21.4 & 43 & 14.3 & -3.861 & 0.000 \\
Kurang $(<60 \%)$ & 140 & 93.4 & 117 & 78.6 & 257 & 85.7 & & \\
\multicolumn{1}{c}{ Total } & 150 & 100 & 150 & 100 & 300 & 100 & & \\
\multicolumn{2}{c}{ Rata-rata \pm SD } & $39.85 \pm 12.221$ & $46.67 \pm 17.825$ & $43.26 \pm 15.635$ & & \\
\hline
\end{tabular}

Tabel 5. Sebaran Tingkat Persepsi Petani terhadap PRG

\begin{tabular}{cccccccc}
\hline \multirow{2}{*}{ Kategori } & \multicolumn{2}{c}{ Jombang } & \multicolumn{2}{c}{ Deli Serdang } & \multicolumn{2}{c}{ Total } & \multicolumn{1}{c}{ Test } \\
\cline { 2 - 7 } & $\mathrm{n}$ & $\%$ & $\mathrm{n}$ & $\%$ & $\mathrm{~N}$ & $\%$ & $\mathrm{t}$ \\
\hline Menerima & 126 & 84.0 & 115 & 76.7 & 241 & 80.3 & 2.030 \\
Tidak Menerima & 24 & 16.0 & 35 & 23.3 & 59 & 19.7 & 0.360 \\
Total & 150 & 100 & 150 & 100 & 300 & 100 & \\
Rata-rata \pm SD & $74.29 \pm 15.387$ & $70.50 \pm 16.886$ & $72.39 \pm 16.238$ & \\
\hline
\end{tabular}


Tabel 6. Hasil Uji Hubungan Pendidikan, Pengetahuan dan Persepsi Petani terhadap PRG

\begin{tabular}{llrrr}
\hline & & Pendidikan & Pengetahuan & \multicolumn{1}{c}{ Persepsi } \\
\hline Pendidikan & Koefisien Korelasi & 1.000 & $0.195^{* *}$ & 0.009 \\
& Sig & & 0.001 & 0.879 \\
& $\mathrm{n}$ & 300 & 300 & 300 \\
Pengetahuan & Koefisien Korelasi & $0.195^{* *}$ & 1.000 & 0.083 \\
& Sig & 0.001 & 300 & 0.153 \\
& $\mathrm{n}$ & 300 & 300 \\
Persepsi & Koefisien Korelasi & 0.009 & 0.083 & 1.000 \\
& Sig & 0.879 & 0.153 & 300 \\
\hline
\end{tabular}

${ }^{* *}=$ Kolerasi signifikan pada taraf 0.01

\section{Harapan Petani terhadap PRG dan Pertanian di Indonesia}

Dari 300 petani hanya 150 atau $50.0 \%$ petani yang memberikan jawaban untuk aspek harapan terhadap peredaran dan perkembangan PRG. Dari 150 orang petani yang memberikan jawaban, sebanyak $30.3 \%$ menyatakan PRG terutama produk pangan bisa diedarkan jika mampu memberikan kualitas hasil yang tinggi, harga benih yang murah dan mudah diperoleh. Selanjutnya, sebanyak $18.4 \%$ petani berharap dengan adanya PRG dapat meningkatkan produktivitas pertanian di Indonesia. Harapan yang diberikan oleh petani di duga karena selama ini petani selalu berada dalam posisi yang semakin lemah dan kurang mendapatkan keuntungan. Biaya produksi pertanian yang semakin tinggi tidak disertai dengan peningkatan pendapatan petani karena harga jual gabah dari petani pun semakin rendah, sedangkan mereka hanya bergantung dari sektor pertanian.

\section{KESIMPULAN}

Status tanaman PRG terutama tanaman pangan masih dalam tahap penelitian dan pengembangan di tingkat institusi dan belum ada tanaman PRG yang telah dilepas untuk ditanam secara luas di Indonesia. Satu-satunya produk PRG yang telah dilepas dilingkungan adalah kapas NU Coton 35B (Bolgard) di Sulawesi Selatan. Pemerintah Indonesia telah mengambil sikap pro dengan penuh kehati-hatian dalam pengembangan tanaman transgenik di Indonesia. Tanaman transgenik yang akan dilepas di Indonesia diuji melalui penelitian dan pengembangan yang baik, terencana, dan berkelanjutan.

Beberapa produk PRG impor seperti kedelai dan jagung serta komponen-komponennya telah beredar di Indonesia. Komponen dari kedelai dan jagung PRG digunakan untuk bahan tambahan pangan atau ingredient makanan/minuman dalam industri pangan.

Hasil analisis penerimaan petani terhadap PRG diketahui 59.7 \% petani menyatakan menerima PRG, dimana skor penerimaan terhadap PRG pada petani di kabupaten Deli Serdang lebih baik bila dibandingkan dengan skor penerimaan petani di Kabupaten Jombang. Hasil uji regresi logistik menunjukkan hanya variabel pengetahuan yang mempengaruhi penerimaan petani terhadap PRG, sedangkan variabel persepsi, pendidikan, keanggotaan dalam perkumpulan kelompok tani, dan pendapatan tidak mempengaruhi penerimaan petani terhadap PRG.

Sebanyak $14.3 \%$ petani mempunyai tingkat pengetahuan yang baik tentang PRG. Hasil Uji t yang dilakukan untuk melihat perbedaan pengetahuan antara petani di kabupaten Jombang dan petani di Kabupaten Deli Serdang diperoleh hasil terdapat perbedaan yang nyata pada tingkat pengetahuan petani terhadap PRG di dua wilayah tersebut.

Sebanyak $80.3 \%$ petani memiliki persepsi menerima terhadap PRG. Mayoritas petani setuju jika di Indonesia telah beredar produk pangan dan non pangan PRG. Hasil Uji t yang dilakukan untuk melihat perbedaan persepsi antara petani di kabupaten Jombang dan Kabupaten Deli Serdang diperoleh hasil bahwa tidak terdapat perbedaan yang nyata untuk persepsi petani tentang PRG di dua wilayah tersebut.

Hasil analisis hubungan pendidikan dengan pengetahuan dan persepsi petani tentang PRG menggunakan analisis korelasi Spearman's, menunjukkan bahwa variabel pendidikan mempunyai hubungan yang erat dengan variabel pengetahuan pada taraf signifikansi $<0.01$.

Harapan yang diberikan petani terkait dengan peredaran PRG dan perkembangan 
pertanian di Indonesia, antara lain produk PRG terutama produk pangan bisa diedarkan jika mampu memberikan kualitas hasil yang tinggi, harga benih yang murah dan mudah diperoleh; produktivitas pertanian di Indonesia harus meningkat dan pemerintah serta instansi terkait dapat memberikan informasi dan sosialisasi tentang PRG pada seluruh masyarakat.

\section{UCAPAN TERIMA KASIH}

Disampaikan kepada Badan Penelitian dan Pengembangan Pertanian Departemen Pertanian dan Lembaga Penelitian dan Pemberdayaan Masyarakat Institut Pertanian Bogor, melalui kegiatan Kerjasama Kemitraan Penelitian Pertanian dengan Perguruan Tinggi.

\section{DAFTAR PUSTAKA}

Anonim. 2006. Produk transgenik masuk Indonesia. http://www.kompas.com/ kompascetak/0607/17/ekonomi/281193 4.htm [17 Oktober 2007].

Barmawie N, Bahagiawati AH, Mulya K, Santoso D, Sugiarto B, Juliantini E, Syahyuti, Erizal, Hasnam, Herman M, \& Trisyono YA. 2003. Perkembangan dan Dampak Pelepasan Produk Rekayasa Genetika (PRG) dan Produk Komersialnya (Kasus kapas Bollgard dan Kedelai Impor). Departemen Pertanian, Balai Penelitian Bioteknologi dan Sumber Daya Genetika Pertanian, Proyek National Biosafety Framework GEF-UNEP, Kementerian Lingkungan Hidup.
Hardinsyah. 2000. Potensi Kekuatan dan Kelemahan Produk Pangan Hasil Rekayasa Genetika. Makalah pada Seminar Pangan Rekayasa Genetika. Kolaborasi, Bogor

ISAAA (International Service for the Acquisition of Agri-Biotech Applications). 2007. Brief 37-2007: Executive Summary, Global Status of Commercialized Biotech/ GM Crops: 2007 in http://www.isaaa. org [2 Januari 2008].

Mulya K, et al. 2003. Status Pengaturan Dan Keamanan Pemanfaatan Produk Rekayasa Genetika di Indonesia. Departemen Pertanian, Balai Penelitian Bioteknologi dan Sumber Daya Genetika, proyek National Biosafety Framework GEF-UNEP, Kementrian Lingkungan Hidup.

Santosa DA. 2002. Pangan transgenik. http:// www.gizi.net/cgibin/berita/fullnews.cgi ? newsid1013491543,87388. [17 Oktober 2007].

Swastika DKS dan Hardinsyah. 2008. Kebijakan Produksi dan Peredaran Produk Pertanian Hasil Rekayasa Genetika (PRG) di Indonesia. Prosiding: Analisis Kebijakan Pertanian. Pusat Analisis Sosial Ekonomi dan Kebijakan Pertanian, Badan Litbang Pertanian, Departemen Pertanian, Bogor.

Sekretariat Dewan Ketahanan Pangan. 2001. Posisi Pemerintah mengenai Pengembangan dan Pemanfaatan Pangan Rekayasa Genetika. Sekretariat Dewan Ketahanan Pangan, Jakarta. 